\title{
Evaluation of Hydrocarbon Generated and Expelled from the Jurassic to Early Cretaceous Source Rocks in the Lynedoch Field, Northern Bonaparte Basin, Australia
}

\author{
Rakotondravoavy Jules ${ }^{1,2}$, Jiaren Ye', Qiang Cao ${ }^{1}$ \\ ${ }^{1}$ Key Laboratory of Tectonics and Petroleum Resources, China University of Geosciences, MOE, \\ Wuhan, China \\ ${ }^{2}$ Département des Sciences de la Terre et de l'Environnement à la Faculté des Sciences, de Technologies et de \\ I'Environnement de l'Université de Mahajanga, Mahajanga, Madagascar \\ Email: "rakoto@mail.ru
}

Received 19 March 2016; accepted 24 April 2016; published 27 April 2016

Copyright (C) 2016 by authors and Scientific Research Publishing Inc.

This work is licensed under the Creative Commons Attribution International License (CC BY).

http://creativecommons.org/licenses/by/4.0/

(c) () D Den Access

\section{Abstract}

The Lynedoch field is located on the west flank of the Calder Graben in the north-eastern Bonaparte Basin, Australia. The data from the wells Lynedoch 1 and Lynedoch 2 and Seismic Line N11809 were used to reconstruct the burial and thermal histories and evaluate the hydrocarbon generated and expelled from the Jurassic to Early Cretaceous source rocks of the study area. Basin Mod 1-D and 2-D softwares were used for modeling. The Upper Jurassic Cleia (Lower Frigate) and Lower Cretaceous Echuca Shoals formations source rocks in the well Lynedoch 1 were a fair-togood source richness with poor hydrocarbon generating potential, showing kerogen type III and gas prone. The Middle Jurassic Plover Formation source rock in the well Lynedoch 2 was a good organic matter richness with poor hydrocarbon generative potential, the late Middle Jurassic (Callovian) Elang Formation source rock in the same well was a fair source rock with poor hydrocarbon generation potential, and the Lower Cretaceous Echuca Shoals Formation source rock in the same well was a fair-to-very good organic richness with poor-to-fair hydrocarbon generating potential, gas prone with kerogen type III, and reaching wet gas window at present day. These previous formations of the both wells generated oil at the Late Cretaceous and gas at the Early Neogene. But, only Echuca Shoals Formation source rock in the well Lynedoch 2 was able to expelled hydrocarbon at the Middle Paleogene and continued up to present day. This Formation represents fair to slightly good potential source rock in the Lynedoch field.

\footnotetext{
"Corresponding author.
}

How to cite this paper: Jules, R., Ye, J.R. and Cao, Q. (2016) Evaluation of Hydrocarbon Generated and Expelled from the Jurassic to Early Cretaceous Source Rocks in the Lynedoch Field, Northern Bonaparte Basin, Australia. International Journal of Geosciences, 7, 584-597. http://dx.doi.org/10.4236/ijg.2016.74045 


\section{Keywords}

\section{Calder Graben, Hydrocarbon Generation, Hydrocarbon Expulsion, Lynedoch Field, Northern Bonaparte Basin}

\section{Introduction}

The Lynedoch field is located on the west flank of the Calder Graben, northern Bonaparte Basin, Australia. It is referred to as the Malita Graben, which trends in a NEE-SWW direction except on its northern end where it swings around to a more NE trend. The Lynedoch field contains two wells Lynedoch 1 and Lynedoch 2 (Figure 1). The well Lynedoch 1 is located offshore, $232 \mathrm{~km}$ NNW of Darwin and is drilled on a low relief, anticlinal structural, to test the hydrocarbon potential of the Calder Graben. The well penetrated a Jurassic (Oxfordian age) to Tertiary sequence of sedimentary rocks and encountered a thin hydrocarbon-bearing zone (9.7 m, probably gas) within the Lower Cretaceous carbonate interval at 3674 - $3715 \mathrm{~m} \mathrm{RT}$. The well Lynedoch 2 is located 8.5 km NE of Lynedoch 1, about $350 \mathrm{~km}$ NNW of Darwin. The well was drilled as the primary objective to test sands of the Plover Formation and Darwin Radiolarite as the secondary objective. The stratigraphy penetrated at Lynedoch 2 was as expected with the exception of the presence of the Elang Formation and the absence of the Cleia Formation and encountered about $80 \mathrm{~m}$ of Plover sandstone reservoir. The well was plugged and abandoned as a dry hole with gas shows. The principal source rocks of the northern Bonaparte Basin comprise the shales of the Lower-Middle Jurassic Plover, Middle Jurassic (Callovian) Elang, Upper Jurassic Frigate Shale (Cleia and Flamingo) and the Lower Cretaceous Echuca Shoals formations [1] [2]. Our study aimed at reconstructing the burial and thermal histories and evaluating the hydrocarbon generated and expelled from the Jurassic to Early Cretaceous source rocks of the study area.

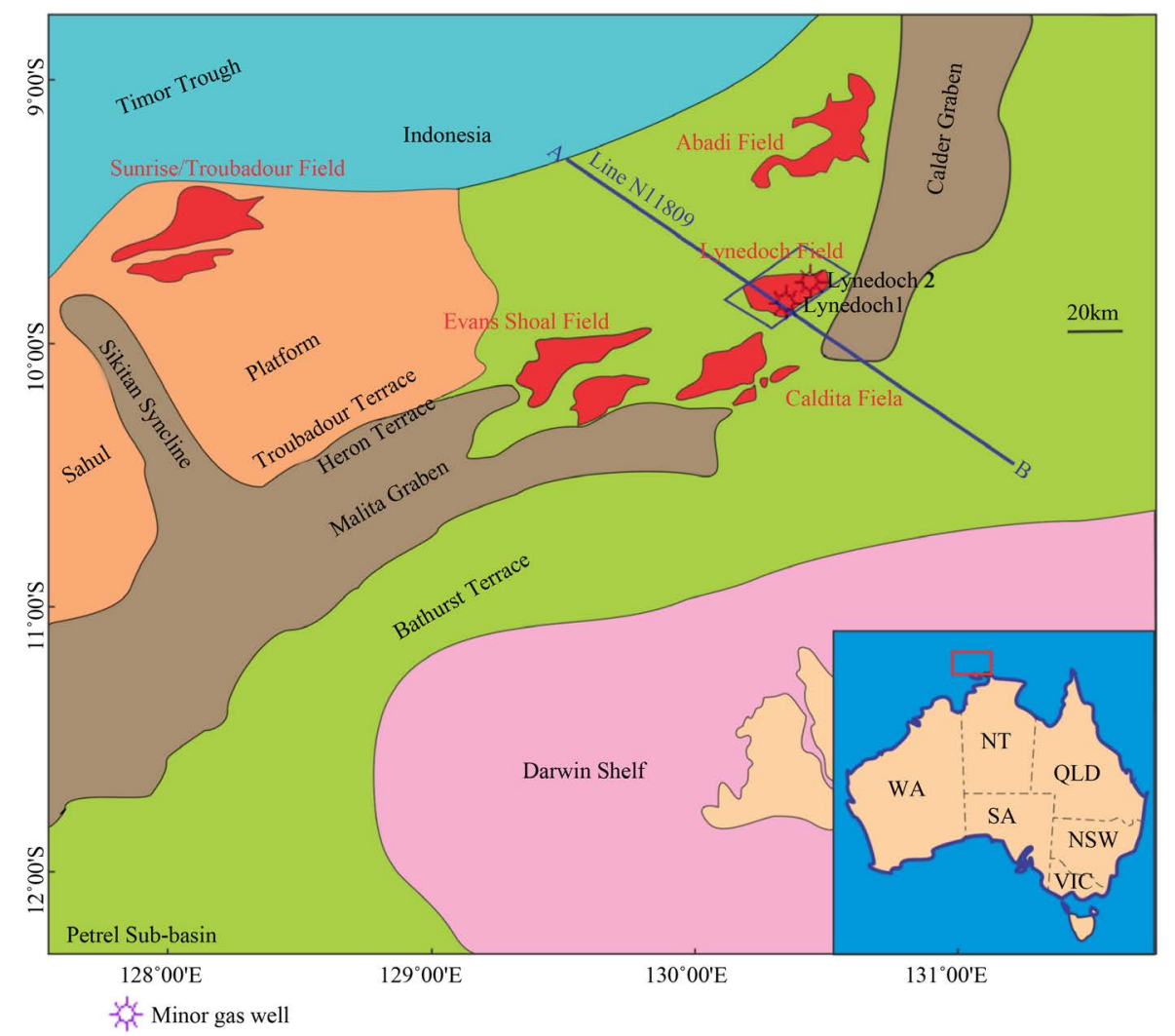

Figure 1. Study area map of the northern Bonaparte Basin, Australia, showing the location of Lynedoch Field, wells Lynedoch 1 and 2, and Seismic Line N11809. 


\section{Geological Setting}

The structural evolution, geological history and stratigraphy of the northern Bonaparte Basin have been described by [3] [4] and summarised by [5] [6]. The northern Bonaparte Basin has been affected by three main phases of rifting. The oldest of these was initiated in the Palaeozoic and has a north-westerly trend. Overprinting this is a Permo-Carboniferous episode of rifting which created a general north-easterly structural grain. A later phase of rifting related to break-up, was initiated as early as the Late Triassic but has its main expression from the Callovian to Kimmeridgian, which led to rapid subsidence and development of the Malita and Calder grabens as major depocentres. The Permian to Recent stratigraphy of the area has been subdivided into three major depositional episodes, Late Permian to Middle Jurassic, Late Jurassic to Early Cretaceous and Early Cretaceous to Recent. Each sequence is bounded by a seismically mappable unconformity or disconformity. The major seismic surfaces are the Callovian Unconformity, Valanginian Unconformity, and Aptian Disconformity (Figure 2). The Upper Permian Hyland Bay Subgroup comprises thick shelfal carbonates interbedded with clastics [7]

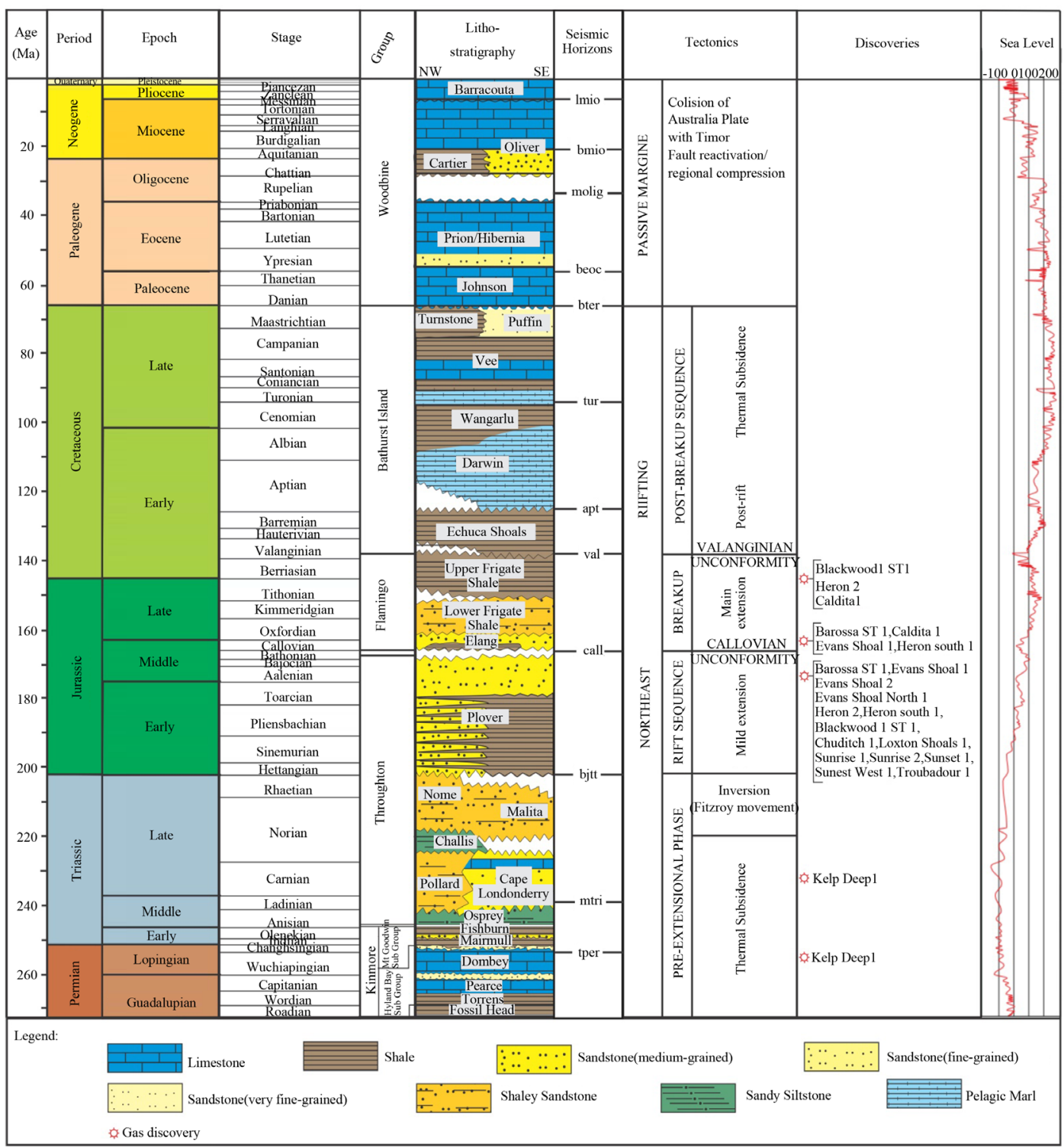

Figure 2. Stratigraphy, tectonics, and petroleum discoveries of the northern Bonaparte Basin, Australia, based on the Bonaparte Basin Biozonation and Stratigraphy Chart 33 (Kelman et al., 2014), showing the short term sea level used for burial history modelled. Geologic Time Scale after Gradstein et al. (2012). Lower Frigate = Cleia and Upper Frigate = Flamingo. 
and overlain by Upper Permian to Lower Triassic Mount Goodwin Subgroup deep marine siltstones, shales, and submarine fan sandstones [8]. The Middle-Upper Triassic Cape Londonderry Formation consists of a mixed carbonate and clastic sequence overlain by fluvial red beds of the Upper Triassic to Lower Jurassic Malita Formation. The Lower-Middle Jurassic Plover Formation is a regionally distributed, fluvio-deltaic sequence of sandstone, siltstone, claystone, and coal. The top of the Plover Formation is defined by the Callovian Unconformity, and in others it is a transgressive surface which marks the base of the Callovian shefal marine Elang Formation. A more significant flooding event occurred at the end of the Callovian, resulting in deposition of the Oxfordian Cleia Formation claystone. The Kimmeridgian Unconformity separates depositional sequences of the Cleia Formation and overlying Bathurst Island Group. In the wells Lynedoch 1 and Lynedoch 2, the unconformity at the top of the Jurassic was developed just prior to continental breakup and erosion during this time removed any record of the Tithonian sediments if deposited. In these both wells of the Lynedoch Field the Flamingo Formation is absent. The Valanginian Unconformity defines the top of the Flamingo Group sequence and the end of the active extension in the region. Overlying the Valanginian Unconformity is the Cretaceous Bathurst Island Group, the basal unit of which is the Echuca Shoals Formation, a glauconitic claystone unit of Valanginian to Barremian age. A prolonged hiatus represented by the Aptian Disconformity marks the top of this unit which is succeeded by the Darwin Formation of Aptian to early Albian age. The overlying late Albian to Turonian Wangarlu Formation is characterised by a thick sequence of marine claystones, which is in turn overlain by marl and minor carbonate depositional cycles of the Vee Formation. Campanian to Maastrichtian sandstone equivalents (Turnstone Formation) of the Puffin Formation overly the Vee Formation. Thick carbonate wedges developed and prograded north-westwards during the Paleocene (Johnson Formation), Eocene (Hibernia and Prion formations) and Miocene (Oliver Formation). A late Miocene Unconformity related to the collision of the Australian and South East Asian plates represents the base of the Barracouta Formation and the beginning of carbonate progradation in an active margin setting.

\section{Materials and Methods}

\subsection{Materials and Input Parameters}

Data for evaluation of oil and gas generation and expulsion were collected from the wells Linedoch 1 and Lynedoch 2. Data required to run the BasinMod 1-D comprised the top and base wellbore depths, present thicknesses of each stratigraphic unit, the lithology mixes data are derived from composite well logs (Table 1). Biostratigraphy was derived from the sidewall cores that were washed, separated, and analyzed for micro fauna (Foraminifera) and flora (Spores and Pollens). This was done to attribute a presumed age to each studied interval. Kerogen types, total organic carbon content (TOC), kinetic algorithms and results of pyrolysis analyses; the location of wells, and organic thermal indicators include measured mean vitrinite reflectance values; Seabed temperature of 14; measured temperatures by Shell Development (Australia) Pty.Ltd, from wireline logging were adjusted using a correction procedure adapted the literature [9] [10] to calculate subsurface bottom hole temperatures (BHTs) through time; the short term sea level proposed by [11] [12]; geologic time scale 1989 Harland; all mixed parameters, the initial porosity, reciprocal and exponential compaction factors, the matrix density, matrix thermal conductivity, and matrix heat capacity are adopted from the default values in BasinMod Software package. The input data for 2-D BasinMod included 1-D well databases, the Seismic Line N11809 (Figure 3), map coordinates, reference location of all data including faults, names and age ranges of all layers, lithologic characteristics of facies within the layers.

\subsection{Methods}

\subsubsection{One-Dimensional Modeling}

One-dimensional modeling of a single well using BasinMod 1-D was performed to reconstruct the burial, thermal, hydrocarbon generation and expulsion histories. Further, it determined the subsidence and sedimentation rates, as well as maturation parameters, such as the time of onset, peak, and end of oil and wet gas generation and expulsion.

An Exponential Equation of [13] for mechanical compaction that relates porosity to depth was used for porosity calculation as follows:

$$
\phi=\phi_{o} \exp ^{(-k z)}
$$




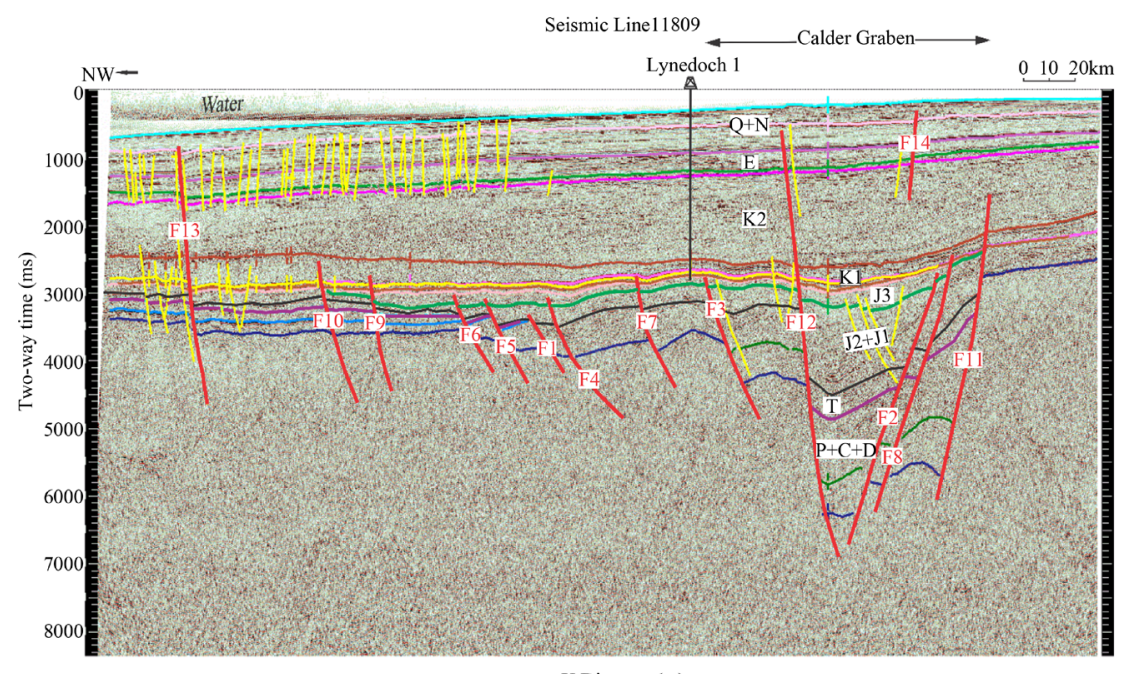

$\mathrm{X}$ Distance (m)

Figure 3. Two-dimensional Seismic Line N11809 through the well Lynedoch 1, which location shown in Figure 1. The formation names are indicated in black capital alphabets: $\mathrm{Q}+\mathrm{N}=$ Oliver, Barracouta and Alaria formations; $\mathrm{E}=$ Johnson, Hibernia and Cartier formations; $\mathrm{K}_{2}=$ Vee, Turnstone and Johnson formations; $\mathrm{K}_{1}=$ Echuca Shoals, Darwin and Wangarlu formations; $\mathrm{J}_{3}=$ Elang and Frigate Shale (Cleia, Flamingo) formations; $\mathrm{J}_{2}+\mathrm{J}_{1}=$ Plover Formation; $\mathrm{T}=$ Mount Goodwin Subgroup, Pollard, Cape Londonderry, Challis, Nome, and Malita formations and P + C + D = Fossil Head Formation, and Hyland BaySubgroup. The faults are indicated in red capital letters: F1 to F14.

Table 1. Geological layers, top and base depths for the wells Lynedoch 1 and Lynedoch 2 in the Lynedoch Field, and lithology used as input parameters for the BasinMod 1-D. Lithological data were compiled from their composite well logs.

\begin{tabular}{|c|c|c|c|c|}
\hline Well & Lynedoch 1 & & Lynedoch 2 & \\
\hline Formation & Lithology & $\begin{array}{l}\text { Top Depth } \\
\text { (m RT) }\end{array}$ & Lithology & $\begin{array}{l}\text { Top Depth } \\
\text { (m RT) }\end{array}$ \\
\hline Alaria & $100 \%$ limestone & 258 & - & - \\
\hline Barracouta & $5 \%$ shale+ $95 \%$ limestone & 509 & $100 \%$ limestone & 291 \\
\hline Oliver & $\begin{array}{c}10 \% \text { shale }+85 \% \\
\text { limestone }+5 \% \text { dolomite }\end{array}$ & 552 & $\begin{array}{l}20 \% \text { sandstone }+10 \% \text { shale } \\
\quad+70 \% \text { limestone }\end{array}$ & 598 \\
\hline Hibernia & $\begin{array}{l}5 \% \text { sandstone }+19 \% \text { shale } \\
+30 \% \text { limestone }+40 \% \text { dolomite } \\
+5 \% \text { evaporite }+1 \% \text { coal }\end{array}$ & 890 & $\begin{array}{c}7 \% \text { sandstone }+0.65 \text { siltstone } \\
\quad+40 \% \text { limestone }+ \\
51.35 \% \text { dolomite }+1 \% \text { evaporite }\end{array}$ & 1030 \\
\hline Johnson & - & - & $1 \%$ sandstone $+99 \%$ limestone & 1571 \\
\hline Turnstone & $\begin{array}{l}65 \% \text { sandstone }+25 \% \text { shale } \\
+2 \% \text { limestone }+8 \% \text { dolomite }\end{array}$ & 1551 & $\begin{array}{l}40 \% \text { sandstone }+30 \% \text { siltstone } \\
+30 \% \text { shale }\end{array}$ & 1625 \\
\hline Vee & $90 \%$ shale $+10 \%$ limestone & 2210 & $\begin{array}{l}30 \% \text { siltstone }+60 \% \text { shale }+ \\
9 \% \text { limestone }+1 \% \text { dolomite }\end{array}$ & 2569 \\
\hline Wangarlu & $\begin{array}{l}2 \% \text { sandstone }+58 \% \text { shale } \\
\quad+40 \% \text { limestone }\end{array}$ & 3533 & $\begin{array}{l}64 \% \text { siltstone }+18 \% \text { shale } \\
+18 \% \text { limestone }\end{array}$ & 3652 \\
\hline Darwin & $60 \%$ shale $+40 \%$ limestone & 3691 & $\begin{array}{l}7.5 \% \text { siltstone+ } 18 \% \text { shale } \\
+74.5 \% \text { limestone }\end{array}$ & 3773 \\
\hline Echuca Shoals & $\begin{array}{l}40 \% \text { siltstone }+55 \% \text { shale } 2.5 \% \\
\text { limestone }+2.5 \% \text { dolomite }\end{array}$ & 3825 & $\begin{array}{l}20 \% \text { siltstone }+70 \% \text { shale } \\
+10 \% \text { limestone }\end{array}$ & 3820 \\
\hline $\begin{array}{c}\text { Cleia } \\
\text { (Lower Frigate Shale) }\end{array}$ & $75 \%$ sandstone $+25 \%$ shale & 3917 & - & - \\
\hline Elang & - & - & $\begin{array}{l}19.5 \% \text { sandstone }+67.8 \% \text { siltstone } \\
\quad+12 \% \text { shale }+0.7 \% \text { limestone }\end{array}$ & 4057 \\
\hline Plover & - & - & $\begin{array}{l}81 \% \text { sandstone }+4.5 \% \text { siltstone } \\
+14.5 \% \text { shale }\end{array}$ & 4102 \\
\hline Base Depth (m) & & 3967 & & 4225 \\
\hline
\end{tabular}

- is no data. RT is Rotary Table. 
where, $\phi$ is the porosity at depth $z, \%$; $\phi_{o}$ is the initial porosity, $\%, K$ is the compaction factor adjusted for varying compressibilities of different lithologies, and $z$ is the depth, $\mathrm{m}$. The method of backstripping was used to reconstruct the burial history. The change in temperature with depth of the study area was:

$$
\text { Geothermal gradient }\left({ }^{\circ} \mathrm{C} / \mathrm{m}\right)=\text { Change in temperature }\left({ }^{\circ} \mathrm{C}\right) / \operatorname{change~in~depth~}(\mathrm{m})
$$

The transient heat flow equation was used to describe the thermal conduction and convention of the heat flow, assuming that the heat transfer in 1-D was by vertical conduction using the following equation:

$$
\begin{gathered}
\frac{\mathrm{d} T(x, t)}{\mathrm{d} t}=\frac{\mathrm{d}}{\mathrm{d} x}\left(\alpha(x) \frac{\mathrm{d} T}{\mathrm{~d} x} Q\right) \\
\alpha(x)=\frac{k}{\rho c}
\end{gathered}
$$

where $\alpha$ is the thermal diffusivity, $T$ is the temperature $(\mathrm{K}), k$ is the thermal conductivity $\left(\mathrm{W} / \mathrm{m} \cdot{ }^{\circ} \mathrm{C}\right), c$ is the heat capacity $\left(\mathrm{kJ} / \mathrm{m}^{3} \cdot{ }^{\circ} \mathrm{C}\right), t$ is the time (Ma), $\rho$ is the density $\left(\mathrm{g} / \mathrm{cm}^{3}\right), Q$ is the heat source term $(\mathrm{KJ})$ and $x$ is the depth (m).

The total organic carbon content (TOC) versus potential yield $(\mathrm{S} 1+\mathrm{S} 2)$ was used to determine the potential generating hydrocarbon. Modified [14] by [15], oxygen index (OI) versus hydrogen index (HI) for the characterisation of kerogen types, and measured mean VR and IR (\%) versus Depth for thermal maturity.

Predicted maturation and timing of hydrocarbon generation and expulsion were based on Lawrence Livermore National Laboratory (LLNL) vitrinite and kerogen kinetics. The saturated threshold was set to 0.02 for expulsion and migration along the carrier beds driven by excess pressure, buoyancy pressure, and capillary pressure [16] [17].

Maturation stages and their corresponding vitrinite reflectance values are as follows: $0.0 \%-0.5 \% R_{0}$ is the immature zone, $0.5 \%-0.7 \% \mathrm{R}_{0}$ early mature (oil), $0.7 \%-1.3 \% \mathrm{R}_{0}$ late mature (oil), $1.3 \%-2.6 \% \mathrm{R}_{0}$ is the main gas generation, and $2.6 \%-5.0 \% \mathrm{R}_{0}$ is dry gas generation zone.

\subsubsection{Two-Dimensional Modeling}

Two-dimensional modeling was applied to scan input 2-D seismic line N11809 that crossed the study area in the northwest-southeast trend and comprising eight stratigraphic horizons that best depicted the structure and maturity histories. Whereas Two-Way-Time (milliseconds) conversions to depths in meters was done outside of BasinMod 2-D.

The transient heat flow equation of BasinMod 2-D was also used to describe the lateral and vertical thermal conduction and convection of the heat flow of the study area.

\section{Results and Discussion}

\subsection{Source Rock Richness and Hydrocarbon Generation Potential}

The measurements of TOC and thermal cracking of the organic matter by pyrolysis (S1 and S2 mg HC/g rock) are essential in evaluating source rock richness and hydrocarbon generation potential [18]. Interpretations of Rock-Eval pyrolysis parameters used to assess source rock quality and hydrocarbon generation potential were carried out as stated by the standard guidelines suggested by [19]. The Echuca Shoals Formation source rock in the well Lynedoch 1 had five (5) TOC and S1 + S2 ranging from 0.57 to $1.70 \mathrm{wt} \%$ with an average of $1.14 \mathrm{wt} \%$ and from 0.26 to $2.2 \mathrm{mg} \mathrm{HC} / \mathrm{g}$ rock with an average of $1.05 \mathrm{mg} \mathrm{HC} / \mathrm{g}$ rock, respectively (Table 2). This indicated a fair-to-good organic matter richness with poor hydrocarbon generative potential. Similarly, the Cleia (Lower Frigate) Formation source rock in the same well contained three (3) TOC and S1 + S2 varying from 0.69 to $1.78 \mathrm{wt} \%$ with an average of $1.10 \mathrm{wt} \%$ and from 0.41 to $2.43 \mathrm{mg} \mathrm{HC} / \mathrm{g}$ rock with an average of $1.11 \mathrm{mg} \mathrm{HC/g}$ rock, respectively. The Echuca Shoals Formation source rock in the well Lynedoch 2 comprised seventeen (17) TOC and S1 + S2 ranging from 0.63 to $3.48 \mathrm{wt} \%$ with an average of $1.73 \mathrm{wt} \%$ and from 0.39 to $5.59 \mathrm{mg} \mathrm{HC} / \mathrm{g}$ rock with an average of $2.55 \mathrm{mg} \mathrm{HC/g}$ rock, respectively. This indicated a fair-to-very good organic matter richness with poor-to-fair hydrocarbon generating potential. The Elang Formation source rock in the same well gave a TOC value of $0.88 \mathrm{wt} \%$ and S1 + S2 of $0.91 \mathrm{mg} \mathrm{HC/g}$ rock. This indicated a fair source rock with poor hydrocarbon generation potential. In the same well the Plover Formation source rock comprised two (2) TOC 
Table 2. TOC data, mean VR and IR (\%) values and Rock Eval Pyrolysis parameters for the wells Lynedoch 1 and Lynedoch 2, in the Lynedoch field source rock samples.

\begin{tabular}{|c|c|c|c|c|c|c|c|c|c|}
\hline Well Name & Depth (mRT) & Formation & Lithology & TOC (wt\%) & $\begin{array}{l}\mathrm{S} 1+\mathrm{S} 2 \\
(\mathrm{mg} / \mathrm{g})\end{array}$ & HI (mg/g) & OI (mg/g) & Mean VR\% & Mean IR\% \\
\hline \multirow[t]{2}{*}{ Lynedoch 1} & 3837.43 - 3911 & $\begin{array}{l}\text { Echuca } \\
\text { Shoals }\end{array}$ & Shale & $\begin{array}{c}0.57-1.70 \\
1.14(5)\end{array}$ & $\begin{array}{c}0.26-2.22 \\
1.05(5)\end{array}$ & $\begin{array}{c}31.58-93.79 \\
51.07(5)\end{array}$ & $\begin{array}{c}6.21-93.79 \\
45.80(5)\end{array}$ & $\begin{array}{l}1.1-1.39 \\
1.23(3)\end{array}$ & - \\
\hline & $3928.87-3962.40$ & $\begin{array}{l}\text { Cleia } \\
\text { (Lower } \\
\text { Frigate) }\end{array}$ & Shale & $\begin{array}{c}0.69-1.78 \\
1.10(3)\end{array}$ & $\begin{array}{c}0.41-2.43 \\
1.11(3)\end{array}$ & $\begin{array}{c}37.68-91.57 \\
56.50(3)\end{array}$ & $\begin{array}{c}15.73-92.68 \\
60.77(3)\end{array}$ & 1.20 & - \\
\hline \multirow[t]{3}{*}{ Lynedoch 2} & $3824-4050$ & $\begin{array}{l}\text { Echuca } \\
\text { Sholas }\end{array}$ & Shale & $\begin{array}{c}0.63-3.48 \\
1.73(17)\end{array}$ & $\begin{array}{c}0.39-5.59 \\
2.55(17)\end{array}$ & $\begin{array}{c}33.33-131.71 \\
89.31(17)\end{array}$ & $\begin{array}{c}4.03-110.98 \\
21.11(17)\end{array}$ & $\begin{array}{c}1.18-1.26 \\
1.21(4)\end{array}$ & $\begin{array}{c}1.40-1.90 \\
1.70(5)\end{array}$ \\
\hline & $4066-4102$ & Elang & Shale & 0.88 & 0.91 & 59.09 & 6.82 & - & $\begin{array}{c}1.42-1.90 \\
1.66(2)\end{array}$ \\
\hline & $4130-4215$ & Plover & Shale & $\begin{array}{c}1-1.31 \\
1.16(2)\end{array}$ & $\begin{array}{c}0.72-0.82 \\
0.77(2)\end{array}$ & $\begin{array}{c}49.62-61 \\
55.31(2)\end{array}$ & $\begin{array}{l}23-19.85 \\
21.43(2)\end{array}$ & 1.12 & 1.70 \\
\hline
\end{tabular}

where TOC is the total organic matter content (wt\%), VR\% is a vitrinate reflectance, IR\% is an inertinite reflectance; HI is hydrogen index (mg HC/ $\mathrm{g}$ TOC), OI oxygen index ( $\mathrm{mg} \mathrm{CO}_{2} / \mathrm{g}$ TOC); $\mathrm{S} 1+\mathrm{S} 2$ represents the total amount of petroleum that might be generated from a rock in mg HC/g rock (S1 is free hydrocarbon and S2 is the hydrocarbon generation potential of the source rock), -is no data; Minimum value-Maximum value Average (number of samples).

and S1 + S2 varying from 1 to 1.31 wt $\%$ with an average of $1.16 \mathrm{wt} \%$ and from 0.72 to $0.82 \mathrm{mg} \mathrm{HC} / \mathrm{g}$ rock with an average of $0.77 \mathrm{mg} \mathrm{HC/g}$ rock, respectively. This showed a good organic matter richness with poor hydrocarbon generative potential (Figure 4(a)).

\subsection{Source Rock Type}

The source rock type was assessed, based on the modified van Krevelen diagram of Oxygen Index (OI) versus Hydrogen Index (HI) (Figure 4(b)). The HI of Plover, Elang, Lower Frigate Shale and Echuca Shoals formations source rocks in this study was variable from one well to another (Table 2). The Echuca Shoals Formation source rock in the well Lynedoch 1 comprised five (5) HI, which ranged from 31.58 to 93.79 mg HC/g TOC with an average of $51.07 \mathrm{mg} \mathrm{HC} / \mathrm{g}$ TOC, indicated kerogen type III and gas prone. Likewise, the Cleia (Lower Frigate) Formation source rock in the same well contained three (3) HI, varied from 37.68 to $91.57 \mathrm{mg} \mathrm{HC/g}$ TOC with an average of $56.50 \mathrm{mg} \mathrm{HC/g}$ TOC. In the well Lynedoch 2, the Echuca Shoals Formation source rock, seventeen (17) HI readings were recorded, which varied from 33.33 to $131.71 \mathrm{mg} \mathrm{HC/g} \mathrm{TOC} \mathrm{with} \mathrm{an} \mathrm{av-}$ erage of $89.31 \mathrm{mg} \mathrm{HC} / \mathrm{g}$ TOC, showed kerogen type III and gas prone. Similarly Elang Formation source rock in the same well, gave a HI value of $59.09 \mathrm{mg} \mathrm{HC} / \mathrm{g}$ TOC and Plover Formation source rock, two (2) HI readings recorded, varied from 49.62 to $61 \mathrm{mg} \mathrm{HC/g}$ TOC with an average of $51.31 \mathrm{mg} \mathrm{HC} / \mathrm{g}$ TOC. Some source rocks from Echuca Shoals and Cleia (Lower Frigate) formations in the well Lynedoch 1, and Echuca Shoals and Plover formations in the well Lynedoch 2 contained inertinite Type IV kerogen. These pyrolysis results showed that these formations were not expected to generate liquid hydrocarbons.

\subsection{Source Rock Maturity}

Measured mean vitrinite and inertinitereflectances (VR and IR (\%)) values (Figure 4(c)), the calculated based on Easy \%Ro model [20] using BasinMod 1-D software (Figure 5), and the Seismic Line N11809 with BasinMod 2-D (Figure 6) were used to assess the degree of thermal maturity attained by the examined source rocks. The Echuca Shoals Formation source rock in the well Lynedoch 1, three (3) mean VR readings were recorded, which ranged from 1.1 to $1.39 \%$ that have the mean value of $1.23 \%$. This showed late to high-mature with an overall mean of late mature level, corresponding to the depth of 3887.50 and $3909.50 \mathrm{~m}$, respectively, and the Cleia (Lower Frigate) Formation source rock, gave a mean VR value of $1.20 \%$. This indicated late mature level, corresponding to the depth of $3948.50 \mathrm{~m}$. In the well Lynedoch 2, the Echuca Shoals Formation source rock contained four (4) mean VR, ranging from 1.18 to $1.26 \%$ with an average of $1.21 \%$, indicated late mature oil window, corresponding to the depth of 3979 and 3930m, respectively, and the Plover Formation source rock gave a mean VR value of $1.12 \%$. This showed late mature oil window, corresponding to the depth of $4135 \mathrm{~m}$. In the Elang Formation of the well Lynedoch 2, the lack of vitrinite macerals in marine shales with little terrestrial input often requires alternative maturity parameters instead of vitrinite reflectance such as other maceral reflec- 

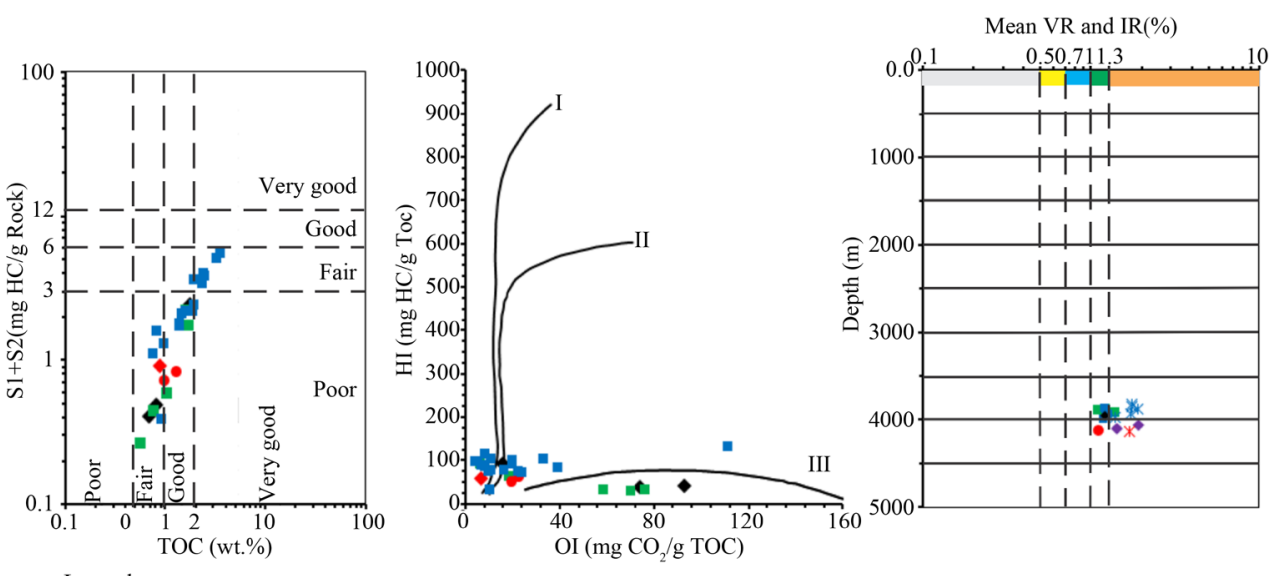

Legend:

-Cleia Fm Lynedoch 1 • Plover Fm Lynedoch 2

-Echuca Shoals Fm Lynedoch 1 • Elang Fm Lynedoch 2

-Echuca Shoals Fm Lynedoch 2 • IR Elang Fm Lynedoch 2

$\square$ Immature

$\square$ Early mature

*IR Plover Fm Lynedoch 2

* IR Echuca Shoals Fm Lynedoch 2

$\square$ Mid mature

$\square$ Late mature

(a)

(b)

(c)

Figure 4. (a) Plot of Total Organic Carbon (TOC) versus potential yield S1 + S2 for the hydrocarbon generation potential; (b) Oxygen Index (OI) versus Hydrogen Index (HI) for organic matter types and (c) Measured mean vitrinate and inertinitereflectances VR and IR (\%) values versus Depth showing thermal maturity of the Plover, Elang, Cleia (Lower Frigate), and Echuca Shoals formations source rocks of the wells Lynedoch 1 and Lynedoch 2. Fm is Formation.
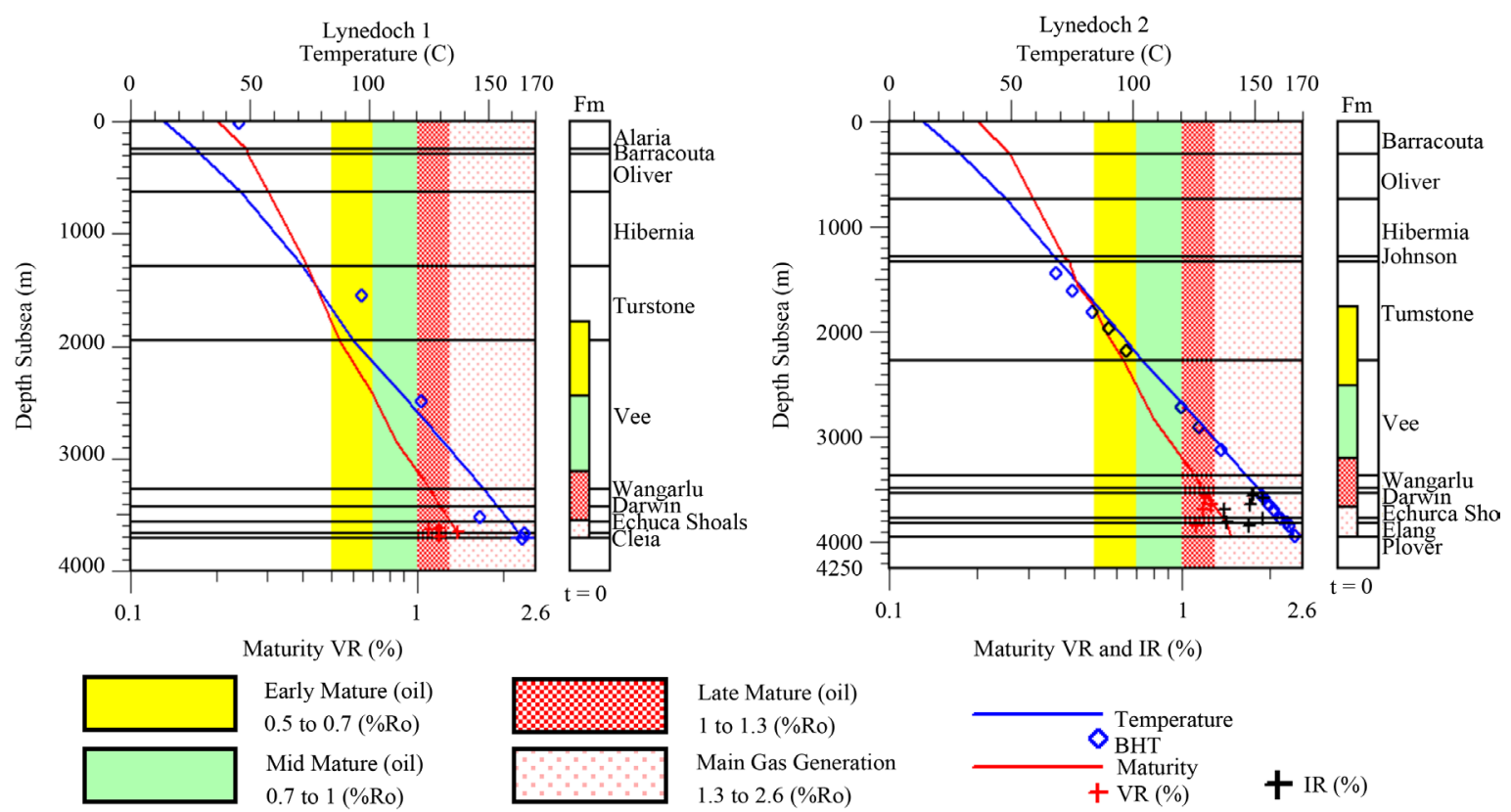

Figure 5. The thermal and maturity histories identifying the fitness of the modelled curves and measuredmean VR and IR, and corrected Temperatures values for the wells Lynedoch 1 and Lynedoch 2.

tance parameters, in our study (e.g. inertinite reflectance). Based on mean inertinite reflectance IR, the Echuca Shoals Formation source rock of the well Lynedoch 2, comprised five (5) mean IR, varying from $1.40 \%$ to $1.90 \%$ with an average of $1.70 \%$, showed high-mature level, corresponding to the depth of 3979 to $3871 \mathrm{~m}$, respectively. The Elang Formation source rock of the same well, two (2) mean IR readings were recorded, which ranged from $1.42 \%$ to $1.90 \%$ that have the mean value of $1.66 \%$. This indicated high-mature level, corresponding to the depth of 4102 to $4066 \mathrm{~m}$, respectively. In the same well, the Plover Formation source rock gave a 
mean IR value of $1.7 \%$, showed high-mature level, corresponding to the depth of $4135 \mathrm{~m}$.

On the other hand, the interpretation of the source rocks maturation levels and hydrocarbons generation across the study area was conducted using the Seismic Line N11809, which is forced by projection of the data from the wells Lynedoch 1 and Lynedoch 2. Thermal history is essential to the timing, amount, and composition of generated hydrocarbons [21]. A total of twenty two (22) corrected temperatures were obtained from these two wells. The seabed temperature was assumed $14^{\circ} \mathrm{C}$. The well Lynedoch 1 reached a total depth of $3967 \mathrm{mRT}$ within the Cleia (Lower Frigate) Formation, and the calculated extrapolated static bottom hole temperature of $164.21^{\circ} \mathrm{C}$, with temperature gradient of $4.05^{\circ} \mathrm{C} / 100 \mathrm{~m}$. The well Lynedoch 2 reached $4225 \mathrm{mRT}$ within the Plover Formation, and bottom hole temperature of $166.38^{\circ} \mathrm{C}$, with temperature gradient of $3.87^{\circ} \mathrm{C} / 100 \mathrm{~m}$. The thermal history identifying the fitness of the corrected values and modelled curves of the temperature in our study is shown Figure 5. The present day heat flow was calculated from sea bottom temperatures, bottom hole temperatures and modelled sediment thermal conductivities. In BasinMod 1-D software, the transient heat flow model can be used to calculate the present-day heat flow. A transient heat flow model was employed to handle the heat transfer in the basin of our study. The modeling results show that the present day heat flow values in the wells Lynedoch 1 and Lynedoch 2 were 62.49 and $58.24 \mathrm{~mW} / \mathrm{m}^{2}$, respectively.

The maturity of the source rocks was interpreted to have been initiated at a level of thermal maturity of $0.5 \%$ $0.7 \%$ Ro and concluded at a level of thermal maturity of $1.3-2.6 \%$ Ro. The maturity evolution history along the Seismic Line N11809 was described as follows: at 95 Ma the Echuca Shoals Formation was immature, at the base of Cleia (Lower Frigate) and Elang formations occurred early mature oil, and middle to late mature oil at the base of the Plover Formation in the study area. In the center of the Calder Graben, theonset of early mature oil occurred at the base of Echuca Shoals Formation, and middle to late mature oil at the base of Elang and Cleia (Lower Frigate) formations, whereas wet to dry gas windows at the base of the Plover Formation (Figure 6(a)). At 65 Ma the threshold of middle to late mature oil took place at the base of Echuca Shoals, Cleia (Lower Frigate) and Elang formations, and wet gas window at the base of the Plover Formation in the study area. In the center of the Calder Graben, at the base of Echuca Shoals Formation occurred middle to late mature oil, and wet gas window at the base of Cleia (Lower Frigate) and Elang formations, whereas wet to dry gas windows at the base of the Plover Formation (Figure 6(b)). At 23.03 Ma the late mature oil to wet gas windows took place at the base of Echuca Shoals Formation, and wet gas window at the base of Cleia (Lower Frigate), Elang and Plover formations in the study area. In the center of the Calder Graben, the threshold of the wet gas window occurred at the base of Echuca Shoals, Cleia (Lower Frigate) and Elang formations, and dry gas window at the base of Plover Formation (Figure 6(c)). At the present day at the base of Echuca Shoals, Cleia (Lower Frigate) and Elang formations took place wet gas window, and wet to dry gas windows at the base of the Plover Formation in the study area. In the center of the Calder Graben, the onset of wet gas window occurred at the base of Echuca Shoals Formation and dry gas window at the base of the Cleia (Lower Frigate), Elang and Plover formations (Figure 6(d)). The modeling results were calibrated to the measured mean vitrinite and inertinitereflectances values for the wells Lynedoch 1 and Lynedoch 2 of the study area, and for the Seismic Line N11809 (Figure 5 and Figure 6), and the correspondence between the simulated and the measured values was remarkably good, which indicated that the accuracy was relatively higher for both 1D and 2D modeling.

\subsection{Hydrocarbon Generation}

The hydrocarbon generation from the source rock has been deduced from its maturation history using correlations between calculated maturity and measured mean vitrinite reflectance and heat flow regime. The amount of gas generated from the source rock in the individual well has been estimated assuming that it is derived from the cracking of oil remaining in the source rock after the oil generation ceased. The beginning of early mature oil window of the Cleia (Lower Frigate) and Echuca Shoals formations source rocks in the well Lynedoch 1 started at Late Cretaceous at the depth of 1164 and $1155 \mathrm{~m}$ corresponding temperature of $92^{\circ} \mathrm{C}$, the mid-mature oil at Late Cretaceous at the depth of about $1756 \mathrm{~m}$ and $1738 \mathrm{~m}$, and at temperature of $120^{\circ} \mathrm{C}$, the late mature oil window during the Middle Paleogene at the depth of about $2676 \mathrm{~m}$ and $2658 \mathrm{~m}$, and at temperature of $139^{\circ} \mathrm{C}$, and the wet gas window in the Early Neogene at the depth of about $3515 \mathrm{~m}$ and $3415 \mathrm{~m}$, and at temperature of 158 and $155^{\circ} \mathrm{C}$, respectively (Figure 7(a)). The amount of generated oil from these two formations were 12.33 and $10.92 \mathrm{mg} / \mathrm{g}$ TOC (Figure 8(a) and Table 3) with generation rate of 0.85 and $0.79 \mathrm{mg} / \mathrm{g}$ TOC $\times$ Ma (Figure 8(b)), and gas were 28.35 and $25.16 \mathrm{mg} / \mathrm{g}$ TOC (Figure 8(a) and Table 3) with generation rate of 1.87 and 1.74 $\mathrm{mg} / \mathrm{g}$ TOC $\times$ Ma (Figure 8(b)), respectively, and they reached the peak generation at the Late Cretaceous. The 


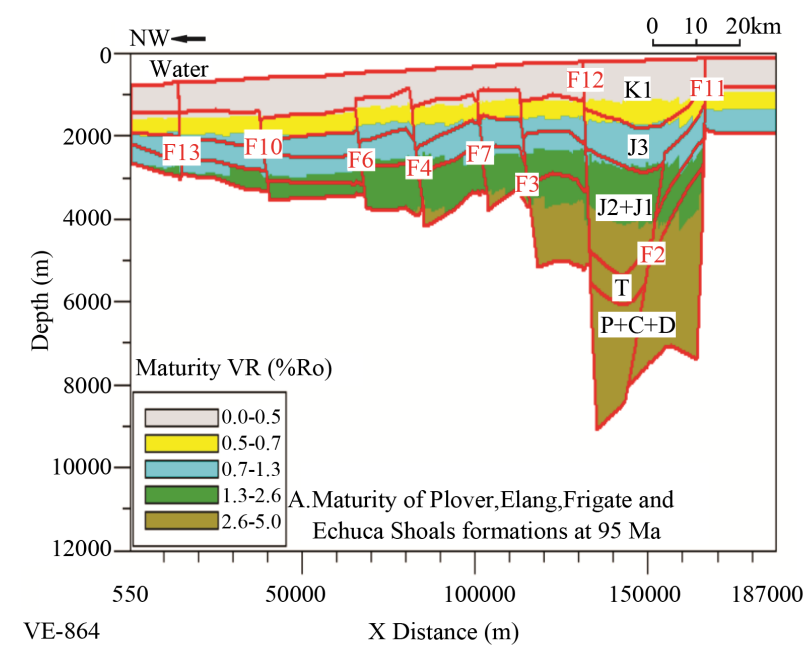

(a)

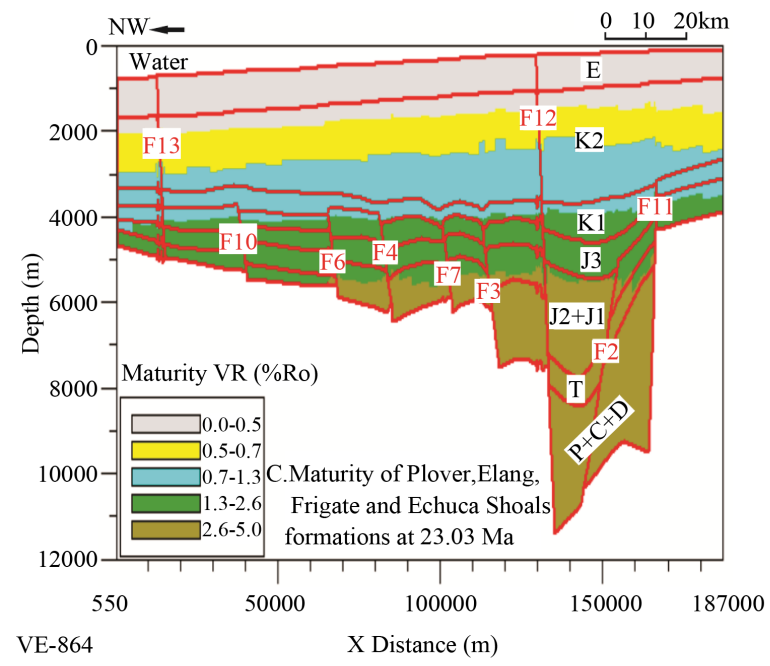

(c)

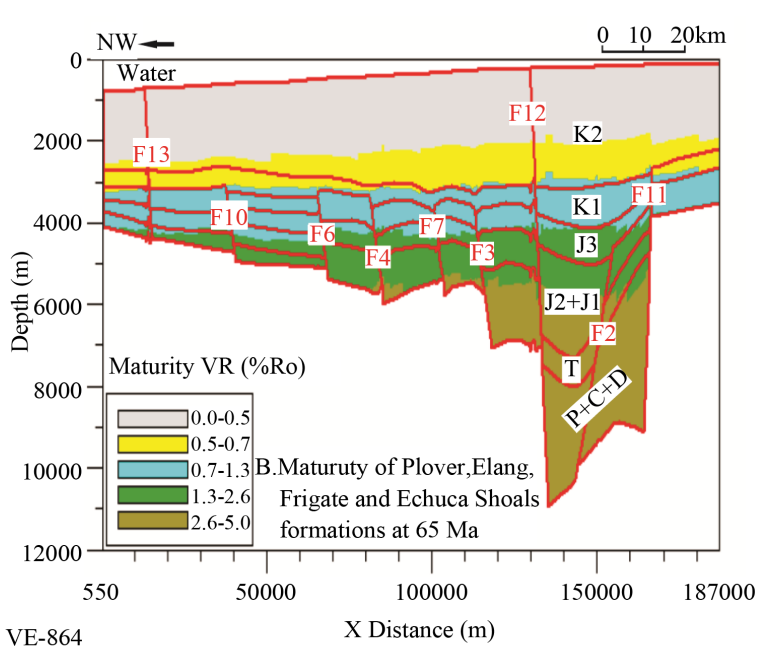

(b)

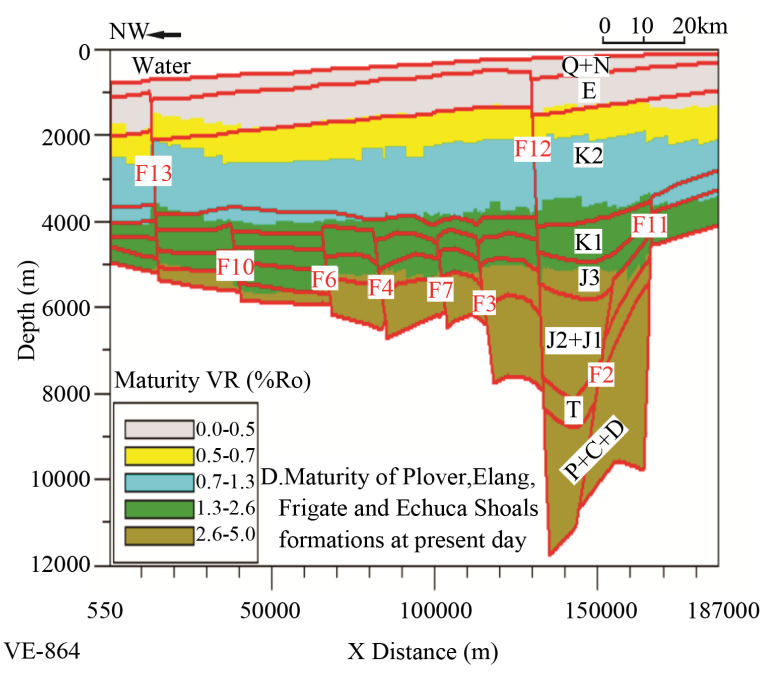

(d)

Figure 6. Schematic diagrams showing the maturity evolution history of the Plover, Elang, Frigate (Cleia and Flamingo) and Echuca Shoals formations source rocks obtained from Seismic Line N11809: (a) source rock maturation at 95 Ma; (b) source rock maturation at $65 \mathrm{Ma}$; (c) source rock maturation at $23.03 \mathrm{Ma}$; (d) source rock maturation at present-day.The formation names are indicated in black capital alphabets: $\mathrm{Q}+\mathrm{N}$ = Oliver, Barracouta and Alaria formations; $\mathrm{E}=$ Johnson, Hibernia and Cartier formations; $\mathrm{K}_{2}=$ Vee, Turnstone and Puffin formations; $\mathrm{K}_{1}=$ Echuca Shoals, Darwin and Wangarlu formations; $\mathrm{J}_{3}=$ Elang and Frigate Shale (Cleia, Flamingo); $\mathrm{J}_{2}+\mathrm{J}_{1}=$ Plover Formation; $\mathrm{T}=$ Mount Goodwin Subgroup, Pollard, Cape Londonderry, Challis, Nome, and Malita formations and P $+\mathrm{C}+\mathrm{D}=$ Fossil Head Formation, and Hyland BaySubgroup. The faults are indicated in red capital letters: F2 to F13.

start of early mature oil window of the Plover, Elang and Echuca Shoals formations source rocks in the well Lynedoch 2began at the Late Cretaceous at the depth of about 1263 m, $1202 \mathrm{~m}$, and $1200 \mathrm{~m}$, and temperature of $90^{\circ} \mathrm{C}$, and the mid-mature oil window during the Late Cretaceous at the depth of $1853 \mathrm{~m}, 1823 \mathrm{~m}$, and $1812 \mathrm{~m}$, and at the temperature of $118^{\circ} \mathrm{C}$, the late mature oil window at the Middle Paleogene at the depth of about 2911 , 2809 and $2779 \mathrm{~m}$, and temperature of $142^{\circ} \mathrm{C}$, and the wet gas window at Early Neogene at the depth of about 3450, 3368 and $3520 \mathrm{~m}$, and at temperature of 155,152 and $153^{\circ} \mathrm{C}$, respectively (Figure 7(b)). The amounts of oil generated from these three formations were 12.35, 13.38, and $19 \mathrm{mg} / \mathrm{g}$ TOC (Figure 9(a) and Table 3) with generation rate of $0.87,0.72$, and $0.83 \mathrm{mg} / \mathrm{g}$ TOC $\times$ Ma (Figure $9(\mathbf{b})$ ), and gas were 31.81, 32.02, and 43.89 mg/g TOC (Figure 9(a) and Table 3 ) with generation rate of 1.92, 1.60, and $1.93 \mathrm{mg} / \mathrm{g}$ TOC $\times$ Ma (Figure 9(b)), respectively, and they reached the peak generation at the Late Cretaceous for the Plover and Elang formations and at Early Paleogene for the Echuca Shoals Formation. 


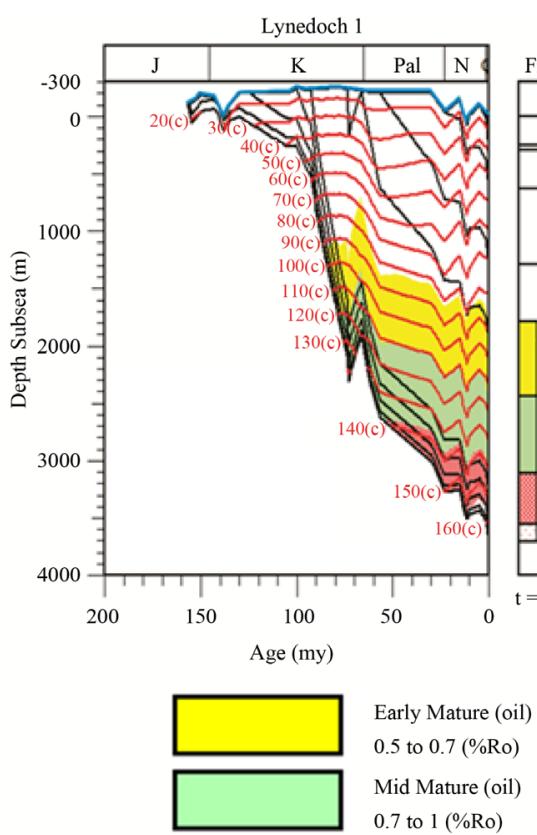

(a)
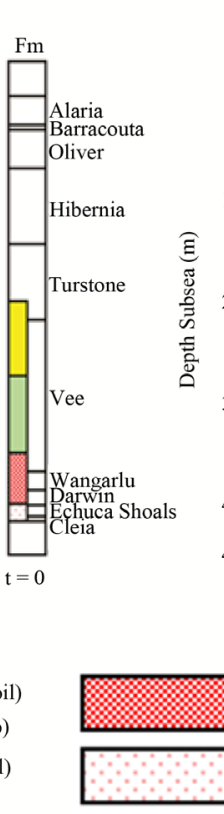

1 to $1.3(\%$ Ro $)$

Main Gas Generation

1.3 to $2.6(\%$ Ro $)$
Lynedoch 2

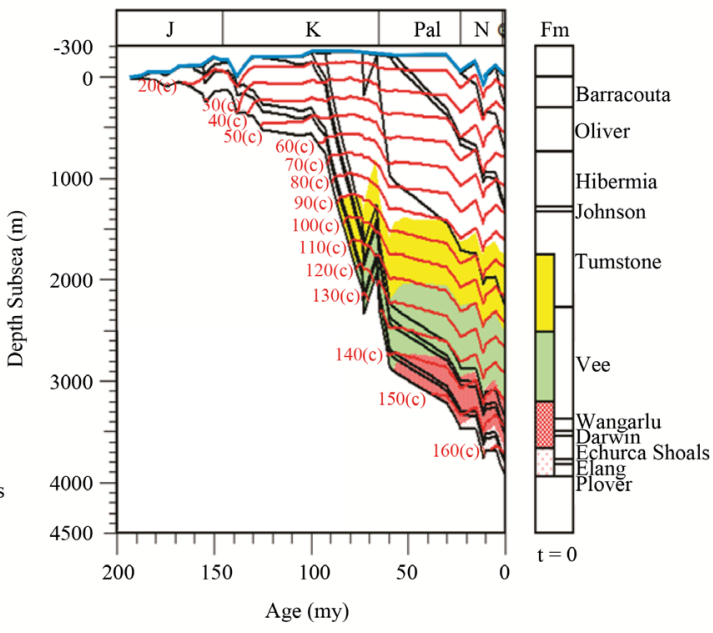

(b)

Figure 7. Modelled burial history of the wells: (a) Lynedoch 1 and (b) Lynedoch 2.

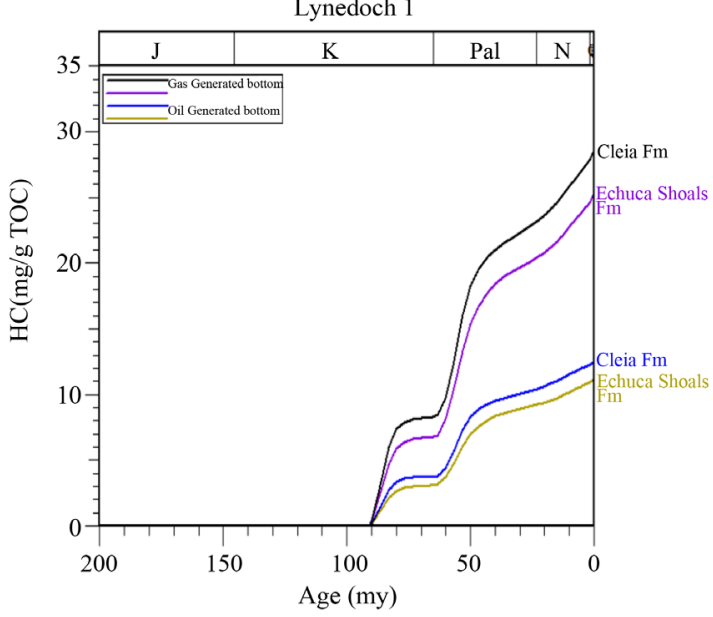

(a)

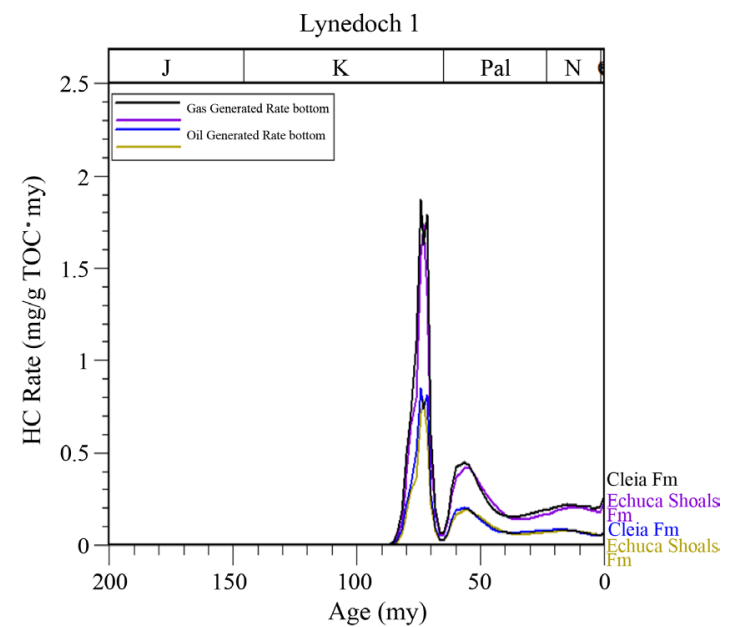

(b)

Figure 8. Modeling results of hydrocarbon generation history in the well Lynedoch 1. (a) Amount of hydrocarbon generation; (b) Rate of hydrocarbon showing the peak generation at the Late Cretaceous.

Table 3. Oil and gas generation, expulsion and efficiencyin the wellsLynedoch 1 and Lynedoch 2.

\begin{tabular}{|c|c|c|c|c|c|c|c|}
\hline \multirow{2}{*}{ Well Name } & \multirow{2}{*}{ Formation } & \multicolumn{3}{|c|}{ Oil } & \multicolumn{3}{|c|}{ Gas } \\
\hline & & $\mathrm{G}_{\text {oil }}$ & $\mathrm{E}_{\mathrm{oil}}$ & $\mathrm{Oil}_{\mathrm{eff}}$ & $\mathrm{G}_{\mathrm{gas}}$ & $E_{\text {gas }}$ & Gas $_{\text {eff }}$ \\
\hline \multirow[t]{2}{*}{ Lynedoch 1} & Echuca Shoals & 10.92 & 0.0 & 0.0 & 25.16 & 0.0 & 0.0 \\
\hline & Cleia (Lower Frigate) & 12.33 & 0.0 & 0.0 & 28.35 & 0.0 & 0.0 \\
\hline \multirow[t]{3}{*}{ Lynedoch 2} & Echuca Shoals & 19 & 8.50 & 45 & 43.89 & 22.38 & 51 \\
\hline & Elang & 13.38 & 0.0 & 0.0 & 32.02 & 0.0 & 0.0 \\
\hline & Plover & 12.35 & 0.0 & 0.0 & 31.81 & 0.0 & 0.0 \\
\hline
\end{tabular}

where $\mathrm{G}_{\mathrm{oil}}$ is oil generating intensity (mg/g TOC); $\mathrm{E}_{\mathrm{oil}}$ is oil expelling intensity (mg/g TOC); Oil $\mathrm{eff}_{\text {is }}$ oil expelling efficiency (\%); $\mathrm{G}_{\mathrm{gas}}$ is gas generating intensity (mg/g TOC); $\mathrm{E}_{\mathrm{gas}}$ is gas expelling intensity (mg/g TOC); $\mathrm{Gas}_{\text {eff }}$ is gas expelling efficiency (\%). 


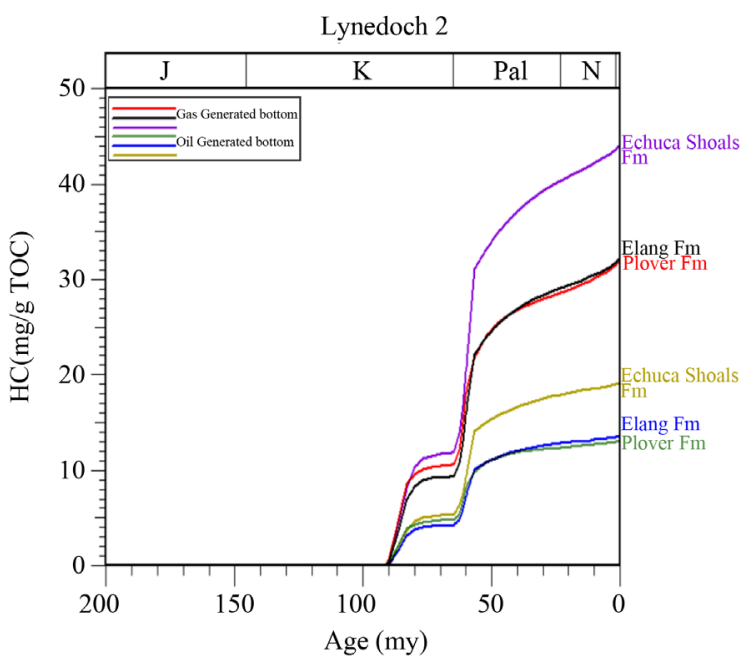

(a)

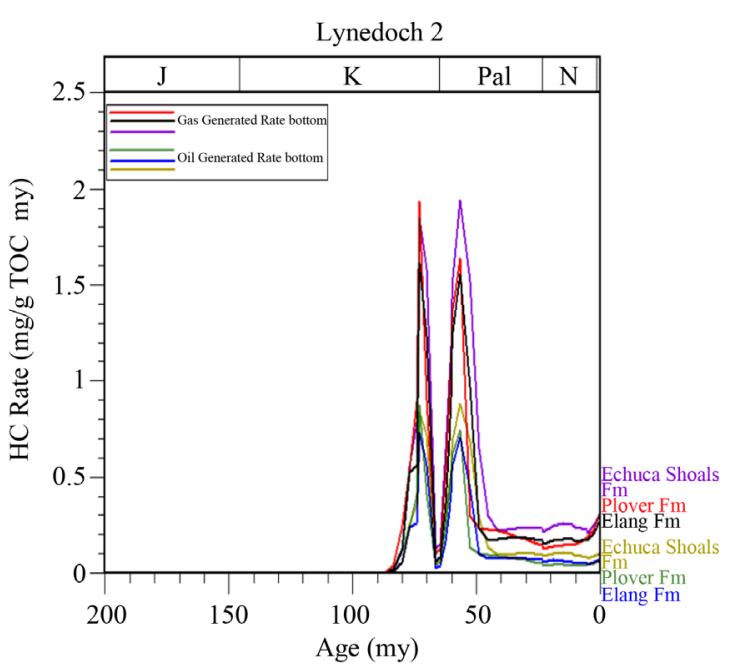

(b)

Figure 9. Modeling results of hydrocarbon generation history in the well Lynedoch 2. (a) Amount of hydrocarbon generation; (b) Rate of hydrocarbon showing the peak generation at the Late Cretaceous for Plover and Elang formations and at Early Paleogene for the Echuca Shoals Formation.

\subsection{Hydrocarbon Expulsion}

Hydrocarbon expulsion is known as primary migration. Hydrocarbons are expelled from a source rock at discrete phases depending on hydrocarbon saturation of the source rock, conduits-micro fractures, and overpressure caused by oil and gas generation and fluid expansion, temperature increase and capillary pressure. The occurrence of hydrocarbon expulsion is assumed to be happened only when both the fluid pressure and hydrocarbon saturation within the pore reach or exceed a critical value. Hydrocarbon expulsion for each well in the Lynedoch field was determined using the BasinMod 1-D. Nil hydrocarbon expelled from the Cleia and Echuca Shoals formations source rocks in the well Lynedoch 1 (Figure 10(a)). Similarly from the Plover and Elang formations source rocks in the well Lynedoch 2 (Figure 10(b)). Only Echuca Shoals Formation source rock in the Lynedoch 2 was able to expelled hydrocarbon, and started at the Middle Paleogene (Figure 10(b)). The expelling intensities of oil and gas from this Formation were 8.50 and $22.38 \mathrm{mg} / \mathrm{g}$ TOC with expelling efficiencies of 45\% and 51\%, respectively (Table 3). These values indicated that the gas show in the Plover Formation of the well Lynedoch 2 has been expelled from the center of the Calder Graben source rock kitchen and gas show within Lower Cretaceous Darwin Formation certainly from the Echuca Shoals Formation, which represents fair to slightly good potential source rock in the Lynedoch field.

\section{Conclusion}

Data from the wells Lynedoch 1 and Lynedoch 2, Seismic Line N11809, with 1-D and 2-D Basin Modeling Softwares were used to reconstruct the burial and thermal histories and evaluate the hydrocarbon generated and expelled from the Jurassic to Early Cretaceous source rocks in the Lynedoch field, northern Bonaparte Basin. The Cleia (Lower Frigate) Formation source rock in the well Lynedoch 1 was a fair-to-good source richness with poor hydrocarbon generating potential, showing kerogen type III gas prone, and reaching wet gas window at the present day, similarly the Lower Cretaceous Echuca Shoals Formation source rock in the same well. The Middle Jurassic Plover Formation source rock in the well Lynedoch 2 was a good organic richness with poor hydrocarbon generative potential, gas prone with kerogen type III, and it attained the wet gas window; the late Middle Jurassic (Callovian) Elang Formation source rock in the same well was a fair source rock with poor hydrocarbon generation potential, gas prone with kerogen type III, and it reached wet gas window, whereas the Lower Cretaceous Echuca Shoals Formation source rock in the same well was a fair-to-very good organic richness with poor-to-fair hydrocarbon generating potential, gas prone with kerogen type III, and reaching wet gas window at present day. The Cleia (Lower Frigate) and Echuca Shoals formations source rocks in the well Lynedoch 1 and Plover, Elang and Echuca Shoals formations in the well Lynedoch 2 generated oil at the Late Cre- 


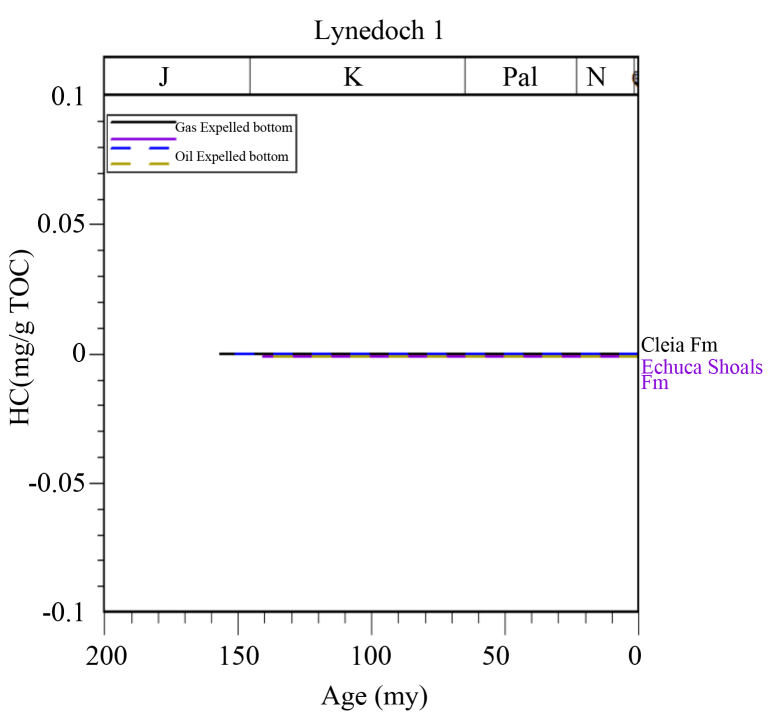

(a)

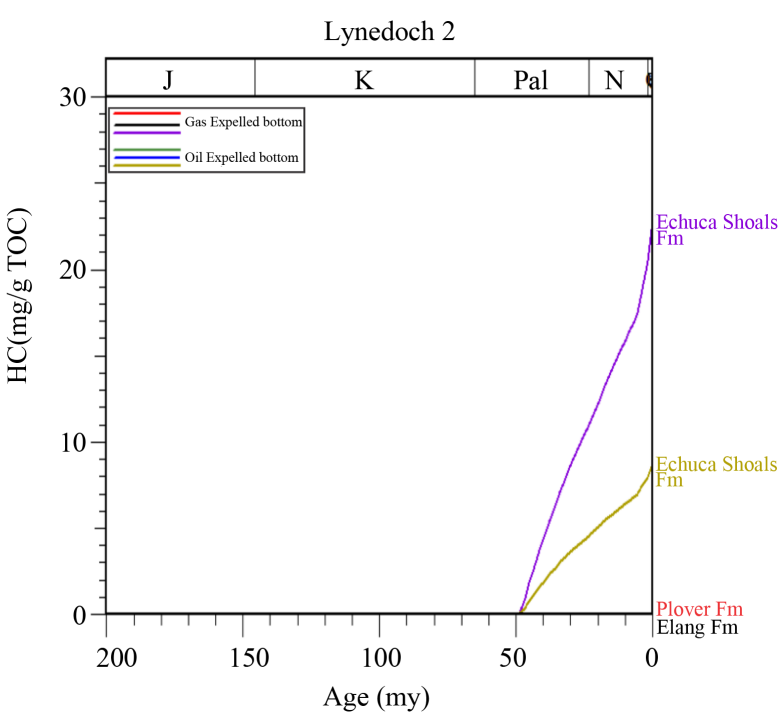

(b)

Figure 10. Modeling results of the oil and gas expulsion history in the wells: (a) Lynedoch 1 and (b) Lynedoch 2.

taceous and gas at Early Neogene. However, only Echuca Shoals Formation source rock in the well Lynedoch 2 was able to expelled hydrocarbon, and started at the Middle Paleogene and continued up to present day. Thus, the gas show in the Plover Formation of the well Lynedoch 2 has been expelled from the center of the Calder Graben source rock kitchen and gas show within Lower Cretaceous Darwin Formation certainly from the Echuca Shoals Formation, which represents fair to slightly good potential source rock in the Lynedoch field. We suggest in the future explore hydrocarbon on the western flank of the Calder Graben throughout Lower Cretaceous Darwin to Lower-Middle Jurassic Plover formations.

\section{Acknowledgements}

The authors would like to thank the Department of Oil and Gas Exploration, Faculty of Earth Resources, China University of Geosciences (Wuhan), for their financial support and the supply of all the data.

\section{References}

[1] Preston, J.C. and Edwards, D.S. (2000) The Petroleum Geochemistry of Oils and Source Rocks from the Northern Bonaparte Basin, Offshore Northern Australia. The APPEA Journal, 1, 257-282.

[2] Abbassi, S., George, S.C., Edwards, D.S., Di Primio, R., Horsfield, B. and Volk, H. (2013) Generation Characteristics of Mesozoic Syn- and Post-Rift Source Rocks, Bonaparte Basin, Australia: New Insights from Compositional Kinetic Modelling. Marine and Petroleum Geology. http://www.sciencedirect.com/science/article/pii/S0264817213002626

[3] Whittam, D.B., Norvick, M.S. and McIntyre, C.L. (1996) Mesozoic and Cainozoic Tectonostratigraphy of Western ZOCA and Adjacent Areas. The APPEA Journal, 1, 209-231.

[4] Shuster, M.W., Eaton, S., Wakefield, L.L. and Kloosterman, H.J. (1998) Neogene Tectonics, Greater Timor Sea, Offshore Australia: Implications for Trap Risk. The APPEA Journal, 1, 351-379.

[5] Ahmad, M. and Musto, T.J. (2013) Chapter 36: Bonaparte Basin. In: Ahmad, M. and Munson, T.J., Eds., Geology and Mineral Resources of the Northern Territory, Northern Territory Geological Survey, Special Publication 5.

[6] Geoscience Australia (2014) Regional Geology of the Bonaparte Basin. Australia 2014 Offshore Petroleum Exploration Acreage Release. http://www.petroleum-acreage.gov.au/files/files/2014/documents/regional-geology/Regional_Geology-Bonaparte.pdf

[7] Gorter, J.D. (1998) Revised Upper Permian Stratigraphy of the Bonaparte Basin. In: Purcell, P.G and Purcell, R.R., Eds., The Sedimentary Basins of Western Australia 2, Proceedings of the Petroleum Exploration Society of Australia Symposium, Perth, 213-228.

[8] Gorter, J.D., Nicoll, R.S., Metcalfe, I., Willink, R.J., and Ferdinando, D. (2009) The Permian-Triassic Boundary in Western Australia: Evidence from the Bonaparte and Northern Perth Basins-Exploration Implications. APPEA Journal, 
49, 311-336.

[9] Oxburg, E.R. and Andrews-Speed. C.P. (1981) Temperature, Thermal Gradients, and Heat Flow in the Southwestern North Sea. In: Illing, L.V. and Hobson, G.D., Eds., The Petroleum Geology of the Continental Shelf of NW Europe, 141-151.

[10] Andrews-Speed, C.P., Oxburg, E.R. and Cooper, B.A. (1984) Temperatures and Depth-Dependent Heat Flow in Western North Sea. AAPG Bulletin, 11, 1764-1784.

[11] Hardenbol, J., Thierry, J., Farley, M.B., Jacquin, T., de Graciansky, P.C. and Vail, P. (1998) Mesozoic and Cenozoic Sequence Chronostratigraphic Framework of European Basins. In: Graciansky, P.C., et al., Eds., Mesozoic and Cenozoic Sequence Stratigraphy of European Basins, SEPM Special Publication 60, 3-13, Charts 1-8.

[12] Haq, B.U. and Shutter, S.R. (2008) A Chronology of Paleozoic Sea-Level Changes. Science, 322, 64-68. http://dx.doi.org/10.1126/science.1161648

[13] Sclater, J.G. and Christie, P.A.F. (1980) Continental Stretching: An Explanation of the Post-mid-Cretaceous Subsidence of the Central North Sea Basin. Journal of Geophysical Research, 85, 3711-3739. http://dx.doi.org/10.1029/JB085iB07p03711

[14] Van Krevelen, D.W. (1961) Coal: Typology-Chemistry-Physics-Constitution. Elsevier, Philadelphia.

[15] Peters, K.E., Walters, C.C. and Moldowan, J.M. (2005) The Biomarker Guide. 2nd Edition, Vol. 1-2, Cambridge University Press, Cambridge.

[16] Schowalter, T.T. (1979) Mechanics of Secondary Hydrocarbon Migration and Entrapment. American Association of Petroleum Geologists Bulletin, 25, 723-760.

[17] England, W.A., Mackenzie, D.M., Mann, D.M., et al. (1987) The Movement and Entrapment of Petroleum Fluids in the Subsurface. Journal of the Geological Society, 144, 327-347. http://dx.doi.org/10.1144/gsjgs.144.2.0327

[18] Peters, K.E., Moldown, J.M., Schoell, M. and Hempkins, W.B. (1986) Petroleum Isotopic and Biomarker Composition Related to Source Rock Organic Matter and Depositional Environment. Organic Geochemistry, 10, 17-27. http://dx.doi.org/10.1016/0146-6380(86)90006-9

[19] Peters, K.E. and Casa, M.R. (1994) Applied Source Rock Geochemistry. In: Magoon L.B. and Dow W.G., Eds., The Petroleum System: From Source to Trap, American Association of Petroleum Geologists, Tulsa, 93-120.

[20] Sweeney, J.J. and Burnham, A.K. (1990) Evaluation of a Simple Model of Vitrinite Reflectance Based on Chemical Kinetics. American Association of Petroleum Geologist Bulletin, 74, 1559-1570.

[21] Ungerer, P. (1993) Modelling of Petroleum Generation and Expulsion—An Update to Recent Reviews. In: Doré, A.G., Augustson, J.H., Hermanrud, C., Stewart, D.J. and Sylta, Ø., Eds., Basin Modelling: Advances and Applications, Norwegian Petroleum Society, Special Publication, Elsevier, Amsterdam, Vol. 3, 219-232. 